\title{
Theological themes in Ricardo's papers and correspondence Sergio Cremaschi
}

This is a text accepted by EJHET on which the published version is based. Please quote from the published versions: The European Journal of the History of Economic Thought, $24 \backslash 4$ (2017), pp. 784-808; reprint in G. Faccarello (ed.), Political Economy and Religion. Essays in the History of Economic Thought, Abingdon: Routledge 2018, pp. 160-184.

\section{Introduction}

I intend to reconstruct David Ricardo's philosophical and theological ideas concerning toleration, religion and morality, and the problem of evil. My reconstruction is carried out on the basis of evidence from the Ricardo Papers, the correspondence and his parliamentary speeches. I will highlight the context of statements he made on several occasions on such topics as the existence of a natural universal morality, the ethical essence of religion, the arbitrariness of any theological speculation and accordingly the uselessness of theology as such, unlimited toleration including even atheists, and the impossibility of theodicy or lack of any answer to the question why there is suffering the world. I will argue that the claims Ricardo endorses are typical of an earlynineteenth-century 'rational Christian' and inspired by his experience as a Jew by birth and education, for a time fellow-traveller of the Quakers, and then a regular hearer at Unitarian services. I shall explore the implications of Ricardo's interest in the religious sceptic Pierre Bayle, and particularly for his argument against theodicy, for his views on the scope and method of political economy. I shall suggest that his view of the function of economic science, more modest than Malthus's, is connected with a less optimistic attitude concerning the possibility of a more egalitarian and humane society. I will add that he believed that political economy should be a secular science precisely for 
theological reasons, namely that the anti-dogmatic kind of religious belief he declared to be rationally legitimate ruled out any kind of dogmatic 'a-theology' like the LaissezFaire Metaphysics cherished by his friend James Mill.

The structure of the paper is as follows: sect. 2 discusses the reasons why philosophico-theological themes in the correspondence and the 'Commonplace Book' were overlooked, first by Sraffa and then by later commentators; sect. 3 discusses the contents of a pamphlet on Christianity in India by Trower and Ricardo's comments; sect. 4 reconstructs the context and contents of Ricardo's parliamentary speech on toleration; sect. 5 is a reconstruction of Ricardo's reading notes on Bayle, Hume and other authors, then an examination of the discussion on theodicy in the correspondence with Mill and Malthus (sects. 6 and 7); finally, in sect. 9 a few conclusions are drawn on Ricardo's views on theology, religious freedom, natural morality, theodicy, and their bearing on political economy.

\section{A hidden agenda in Ricardo's Nachlass}

Readers of recent monographs on Ricardo may have failed to notice the existence of Ricardo's 'Commonplace Book' from the period between 1817 and 1819'. They may find some detailed, albeit scant, information in the Works and Correspondence (Ricardo 1951 - 1973, 10: 393-398), but be left with the impression that nobody since Sraffa, has looked at it again. As in the 'Commonplace Book', consisting actually of a set of notebooks and loose papers containing notes and abstracts, Ricardo's reading plan is also documented in the correspondence with James Mill. Sraffa is as careful as ever in reporting the contents and, with some patience, the most gifted treasure hunters among readers might, for example, be able to reconstruct those passages from Pierre Bayle

\footnotetext{
${ }^{1}$ Weatherall (1976) and Henderson (1997) completely ignore such readings; Milgate and Stimson (1991: 23) and King (2013: 33) do notice them but dismiss them in half a page.
} 
which Ricardo found of special interest. Yet, the criterion followed by Sraffa was to include in the Works and Correspondence just what is directly relevant to economic theory and nothing else. One consequence is, for example, that the Parliamentary discussion on the Christians' Petition is reprinted but the text of the Petition itself is omitted. Another is that Sraffa tends to underestimate the importance of non-economic topics in the correspondence; for instance when Ricardo discusses Trower's pamphlet, and the reader is left without any information about the contents of the publication under discussion; again, when the topic of theodicy emerges, namely in the notes on Malthus and the related correspondence with Mill, the reader is left without information either about the context or the co-text of the discussion. Perhaps the gravest consequence, however, is that information about the 'Commonplace Book' is packed into six pages. Nonetheless, what emerges clearly enough is the fact that $40 \%$ of Ricardo's readings consisted of modern history and travel journals and $60 \%$ of writings about the theory of knowledge and scepticism, the limits of human knowledge in religious subjects, the relationship of religion and morality, toleration, and theodicy or the problem of evil.

\section{Natural and Revealed morality in the correspondence with Trower}

It has been remarked more than once that Ricardo's Principles, when compared with Adam Smith's Wealth of Nations and Malthus's Principles, looks much more like a scientific treatise than a philosophical work. The impression arises from the circumstance that no hint is given of connections either with a philosophical system as a whole or with philosophical or meta-economic claims of any sort. While agreeing that the impression is justified, I am not yet ready to endorse an unjustified inference from so shaky a basis, namely that the Principles look secular because Ricardo himself was 
'secular', an 'unreligious mind' who professed 'atheism'2 . I would object, first, that Ricardo never disclosed atheistic or agnostic leanings, secondly, that when he did discuss theological issues on a few occasions, the opinions he disclosed, far from providing evidence to his privately held atheism or agnosticism, are quite consistent with his public image as a 'rational Christian'.

One example is provided by a letter to Hutches Trower of 8 Nov 1813 where he comments on a pamphlet the latter had published reporting an exchange - letters to the Editor of the Times - between 'Laicus' (pen name of the lawyer and committed Evangelical, John Poynder) and 'an East India Proprietor', that is, Hutches Trower himself. Ricardo, after writing that he had read the letters 'with very great interest' and that his own impression was that all that could be said on the subject had 'been ably said on both sides', concludes:

My opinion coincided with yours before I read your letters and it is now very much strengthened by the facts and reasoning which you have brought forward' (Ricardo 1951 - 1973, 6: 96).

Poynder insists on the idea that Christianity is needed in India, as it is desirable that the faith of the Gospel should supplant the Hindu's absurd, cruel, and immoral superstitions which give room to infanticide, the burning of widows and human sacrifices (Trower 1813: 3-4). He then adds that, in order to achieve this goal, the East India Company should establish an Episcopal Government in India while granting additional facilities to Missionaries to proceed there (Trower 1813: 5-10).

Trower's rejoinders illustrate the alleged dangers carried by an Episcopalian establishment in India with a considerable flow of missionaries. He asserts that 'there are many reasons for deprecating any attempt to convert the Hindoos to Christianity' (Trower 1813: 48) as both impossible and counterproductive (Trower 1813: 13-14),

2 The phrases reported are by Depoortère (2001: 501) and Hartwell (1971: 36); Henderson (1997: 163) instead, somewhat more prudently writes that he was, if 'not atheist, an agnostic'. 
while rejecting the claim that the Hindus are in the most dreadful state of moral depravity' and addicted to 'every vice which can degrade our nature' (Trower 1813: 38), adding that 'their vices are not attributable to their religion' (Trower 1813: 14, 39), that their moral character 'is not deserving of the severity with which it is censured' (Trower 1813: 86-7) and that it 'may be improved without their conversion' (Trower 1813: 87).

From Ricardo's admission that his opinions coincide with Trower's something may be inferred: not his atheism, but rather that he shared the following opinions:

(i) people cannot and should not be forced to believe something whose truth they are not persuaded of;

(ii) morality can be improved independently of adhesion to some given set of religious beliefs;

(iii) the moral character of non-Christian nations is not necessarily perverse;

(iv) the moral character of Christian nations does not necessarily correspond to the purity of the Gospel's teaching.

Another item from Ricardo's correspondence with Trower deserves discussion. In a letter of 26 Jan. 1818, Ricardo mentions John Bird Sumner as 'a clergyman, the author of a clever book on the Records of Creations, in which Malthus's system is not only defended for its truth, but for its affording proofs of the benevolence and goodness of the Creator' (Ricardo 1951-1973, 7: 247). This carries more implications than any reader unaware of the context would draw. The 'clever book' was the Treatise on the Records of Creation (Sumner 1816). This was precisely a treatise on theodicy, trying to improve Paley's argument in his Natural Theology by proving that Malthus's principle of population could be read as one more application of the kind of 'arithmetic' approach to theodicy previously adopted by Paley. In the latter's version, the argument is that the total sum of good in the world may be proved to outweigh that of evil once we define good as pleasure and evil as pain, and we include the total amount of pleasure and pain in the world, that is, that of all sentient beings, even including insects (Paley 1802: 491; cf. Cremaschi 2014: 90-4). Sumner's 'improved' version asserts that the same result is 
reached in a simpler and less extravagant way if we instead define evil as pain and good as moral improvement (Cremaschi 2014: 135-9). In a nutshell, the solution is the following: (i) to some extent, evil will 'arise necessarily from the law of nature', and suffering is necessary in order 'to make men look beyond the present day and the present state of things' (Sumner 1816, 2: 258); (ii) evil is to some extent the result of ineffective institutions which, even when they do not 'positively' teach 'improvidence', are so framed as to discourage the learning of 'prudence' (Sumner 1816, 2: 301); (iii) the main 'cause of the greatest evil of the poor is ignorance' (Sumner 1816, $2: 292$ ), but, as recent improvements in educational systems show, there is a possibility of great improvement in the human mind, and the 'only true secret of assisting the poor is to make them agents in bettering their condition, and to supply them, not with a temporary stimulus, but with a permanent energy' (Sumner 1816, 2: 338-9).

Note that Ricardo, in his usual, calm manner, qualifies the book as 'clever', even though - being persuaded of the impossibility of any theodicy - he was obviously convinced that Sumner's argument was fallacious. Here is his charitable comment:

I am sorry to hear that Mr Sumner does not intend writing any more on Political Economy - his whole attention in future is to be devoted to the study of Theology. Whether in this future pursuit he will have an equal chance of benefiting mankind, as in the former, I have great doubts, or rather have no doubt at all (Ricardo 1951-1973, 7: 247-8).

To the unaware reader, the latter sentence might sound like yet another revelation of an 'unreligious mind'. Instead, what Ricardo is implying here is that theology (not faith) is a vain pursuit. The clarification may be in order here that what was meant by 'theology' at the time was either natural theology (the discussion of the existence and attributes of the Deity on the basis of purely rational argument) or revealed theology (the discussion of the above topics in the light of assertions taken from the Holy Scripture combined with rational argument). Such twofold definition - it is as well to note - fails to overlap with current XXI century meaning, where historical and philological study of Biblical texts and related oral traditions is given pride of place. Theology, thus understood, had been the bête noire of eighteenth-century Aufklärer - 
that is, enlighteners - from all over Europe, including, besides fideist Bayle and deist Voltaire, also Adam Smith, arguably a theist and even a bona fide Presbyterian (Cremaschi forthcoming), and such an orthodox enough Lutheran as Kant. The point of the attack was that theology as commonly understood was an impure mixture of unwarranted metaphysical claims going beyond the reach of human knowledge and assertions about God allegedly found in the Bible which are in fact not there, for although the Bible does teach moral precepts, such as to love one's neighbour, it has a noncommittal attitude vis-à-vis inquiries into God's essence. Besides, while theodicy was a privileged chapter in post-Reformation theology, after the age of Leibniz and the Cambridge Platonists it was unanimously declared a vain enterprise by philosophers. Paley, Sumner and Malthus were the rear guard in an irreparably lost war.

Let me add that Thomas Belsham, the Minister whose services Ricardo attended from 1814 to 1823 (Sraffa 1955a: 39-40; Weatherall 1976: 61-72; Cremaschi 2015), used to teach that faith is a practical attitude, not a theoretical one, that human knowledge is limited and it is useless to inquire into subjects 'without the grasp of the human mind' as Medieval divines used to do, for example into 'the mode of the divine existence' (Belsham 1826 - 1827, 2: 55) and that on 'the most important doctrines of natural and revealed religion' we should not require 'rational knowledge' but rest content instead with 'rational belief' (Belsham 1801: 110).

\section{Toleration in a parliamentary speech}

Milgate and Stimson deserve praise for having drawn attention to Ricardo's political theory as something more than an appendix to his economic theory (Cremaschi 1994). They have argued that his politics have little to share with Benthamite politics, that he 'reached his conclusions before the publication of James Mill's essay on Government' (Milgate and Stimson 1995: 18), that his argument for extension of political rights and religious toleration is not just a reformulation of Bentham's and Mill's arguments, and besides that, at least in his last years, he adopted a markedly pro- 
working class attitude (Milgate and Stimson 1995: 61, 119).

I would add that he had alternative sources for his political ideas. For example, long before he first met Mill, his attendance at Hackney Chapel had offered him the opportunity to meet radicals and reformers of various tendencies. Note, in this connection, that Belsham complained, shortly after 1794, of abandonment of the Pulpit in favour of political militancy by fellow-Ministers (Williams 1833: 462). When Ricardo and Mill first met, the political scenario was changing, radicals were redefining their political stance, and the idea of Reform was to become for many of them the catch-all formula for a new kind of liberalism, fostered by the Philosophical Radicals allied with an assorted company of 'Friends of Reason' in a number of campaigns. In some of these - think of the anti-slave-trade campaign, whose leader was an Evangelical MP - the company was really an oddly assorted one.

Commitment to religious toleration was a matter of course for Ricardo for more than one reason, first as a Jew by birth, secondly as the husband of a Quaker, and thirdly as a Unitarian by choice. Toleration for every kind of religious opinion, including Atheism, was the first point of the Unitarian agenda since Theophilus Lindsey founded the first Unitarian congregation in Britain. Unitarians campaigned for religious toleration for obvious reasons: anti-Trinitarianism was not covered by the Toleration Act of 1689, and up to 1813 still fell under the penal law, and it was not until 1829 that the Corporate and Test Act was abolished (a law depriving Dissenters of full rights) (Stuart 2003; Dave 1978, 65-68; Watts 1998). Let me recall a remarkable comment by Ricardo on toleration for atheists: after a visit to Gatcomb by Sydney Smith, an Edinburgh Review editor, he writes to Mill on 9 Sept. 1821 that Smith 'is always on the liberal side, but has a strong propensity to halt half way - he is for tolerating all religions, but is inclined to be intolerant to those whom he supposes to have no religion. I contended for Dr. Lindsay's principle, that even the Atheist should be heard' (Ricardo $1951-1973,9: 60)^{3}$.

${ }^{3}$ James Lindsay was a Prebyterian Unitarian Minister with whom Ricardo was 
On 26 March 1823, while supporting in Parliament a petition for the release of Marry Ann Carlile who had been imprisoned on the basis of an indictment to have sold atheist literature, he declares that 'a fair and free discussion ought to be allowed on all religious topics' (Ricardo 1951 - 1973, 5: 288). In a letter of 4 April 1823 to Isaac Lyon Goldsmid, a leading figure in the campaign for Jewish emancipation, he writes: 'I carry my principles of toleration very far; - I do not know how, or why any line should be drawn, and am prepared to maintain that we have no more justifiable ground for shutting the mouth of the Atheist than that of any other man' (Ricardo $1951-1973,9$ : 278).

And in fact, Ricardo's Parliamentary Speech on religious freedom was occasioned by a 'Christians' Petition against the Prosecution of Unbelievers', whose 'prime mover' was Aspland (Sraffa 1955a: 41). The petition was presented to the House of Commons by radical MP Joseph Hume and supported by Ricardo. Starting with the argument that 'belief does not in all cases depend upon the will' (Aspland et al. 1823: 363), the petitioners asked the Honourable House to act in order to abolish the possibility of prosecution of unbelievers (Aspland et al. 1823: 364). Ricardo's speech, while referring to Paley and other Anglican authorities, claimed that the law should not establish any limit to discussion on theoretical aspects of religion and that the public authority has no competence to judge whether such discussion is conducted with respect or instead with 'levity and ribaldry', and he vindicated 'a more large and liberal spirit of toleration' (Ricardo 1951 - 1973, 5: 324), contending for 'the general right of self-opinion, and for the unfettered liberty of discussion' $(1951-1973,5: 331)$

The first argument is that imposing profession of belief in a future state is selfdefeating:

what an absurd and immoral mode did the law provide for estimating the credit of a man's faith before his testimony was legally admissible! When

acquainted and who advocated 'not only for Toleration, but for that unbounded freedom of opinion, to which alone genuine Christianity must owe its future prevalence, and its permanent influence' (Lindsay 1813: 22). 
the question was put to a witness, 'Do you believe in a future state?' If he were a conscientious man, entertaining seriously such an opinion, his answer must be in the negative, and the law said he should not be heard; but if he were an immoral man, and disregarded truth, and said, 'I do believe in a future state,' although in his conscience he disbelieved in it, then his evidence was admissible, and his hypocrisy and falsehood secured him credibility. Now, there would be some sense in the law, if it declined tempting the hypocrisy of the individual, or his fear of the world's hostility or prejudice, and let in other evidence to establish, from previous knowledge of the individual, whether or not he ought not to be admitted as a witness; but as it stood, it was absurd and ridiculous (Ricardo 1951 - 1973, 5: 327)

One more argument advanced is that 'on so abstract religious subjects, upon which it was quite impossible to obtain universal assent. No man had a right to say to another, 'My opinion upon religion is right, and yours is not only wrong when you differ from me, but I am entitled to punish you for that difference'" (Ricardo 1955-73, 5: 324-5).

Another is that moral obligation does not arise exclusively from religion, and it has a previous source, the force of 'moral impressions'. Note that, besides being an assertion of the existence of a natural morality, this statement also alludes to a notion utterly incompatible with Benthamite ethics, namely the idea of 'moral impressions'.

The report adds that Ricardo declared that

he firmly believed in the possibility of a man's being very honest for all the social purposes and essential obligations of the community in which he lived, and still not assenting to the belief of a future state. He fully admitted that religion was a powerful obligation, but he denied it to be the only obligation - it was, in fact, one which was superadded to the general force of moral impressions - it were a libel upon human nature to say otherwise (Ricardo 1951 - 1973, 5: 327)

Then he reportedly repeated a neat distinction between opinions on theoretical matters and a capacity to grasp the moral quality of actions. He declared

that the obligation of religion was not alone considered as the test of moral truth, and that a man might be very sceptical upon doctrinal points, and yet very positive in the control of moral impressions distinct from religious faith (Ricardo 1951 - 1973, 5: 328) 
At last he introduced a distinction between positive sciences, where some unerring criteria for ending controversies exist, and other disciplines, bound to remain forever so to say - the battlefield of unending struggles. He said that there was

not in polemics, as in astronomy, one unerring criterion to which the common credence of mankind bowed - it was not like the rising sun, or any of the other phenomena of nature, which were bound by indissoluble and indispensable laws; but, on the contrary, a subject open to conflicting opinions (Ricardo 1951 - 1973, 5: 329).

To sum up: Ricardo's reasons in favour of unlimited religious freedom were typically those endorsed by 'rational Christians', namely, that (i) the essence of religion is morality, not speculative truth; (ii) acceptance of theoretical claims is a matter of rational persuasion, not will; (iii) the non-believer may enjoy as strong moral motivation, deriving from 'moral impressions' independent of opinions on theoretical issues, as the believer; (iv) human nature is good enough to grant that even a nonbeliever may perceive such moral impressions; (v) to controversy on theoretical truths in religion, unlike Astronomy, an end cannot be put by any unerring criteria; (vi) no one has the authority to silence opponents in matters of religious opinion; (vii) any attempt to force profession of religious belief upon non-believers as a proof of their moral accountability would be self-defeating and demoralizing.

\section{Natural morality, theodicy and toleration in the Commonplace Book}

More evidence of Ricardo's interest in theological issues may be found in the 'Commonplace Book', consisting of two notebooks and a few pages of notepaper containing reading notes from 1817 and 1818. Part of this philosophical reading concerns the theory of knowledge and scepticism, including Locke, Hume and Dugald Stewart ${ }^{4}$. I have already mentioned that more than half of it verges on religious subjects.

\footnotetext{
${ }^{4}$ For a reconstruction see Cremaschi and Dascal (1996: 496-7).
} 
Sraffa, though as accurate as ever, seems to have been less than enthusiastic about Ricardo's religious interests and did not allow much room for them. A rather more analytical reconstruction may be of some use.

In the 1817 notebook Ricardo wrote down a select list of titles of chapters with the addition of a number of excerpts copied in full from two of Pierre Bayle's works (Ricardo Papers; cf. Ricardo 1951-1973, 10: 393). The first is Pensées diverses sur la Comète. The topics Ricardo deemed worth examining are, in chs. XLVI, LXXXIV, XCIX, C, CVIII, that opinions keep on being widely shared albeit contradicted by experience just because of their antiquity and generality, and that even visions firmly believed by several witnesses turn out patently false (Bayle 1682: 1, 130-3; 1, 219-21; 1, 266-73; 1, 292-3); in ch. LXIX, that right reason teaches us to honour God not by ceremonies, but rather through the practice of virtue (Bayle 1682: 1, 179-82); in chs. LXXXI and XCI, that religion is constantly used by rulers either to defend themselves or to manipulate their subjects (Bayle 1682: 1, 205-9; 1, 242-4); in ch. LXXXVIII, that conversions obtained by force or bought with money are counterproductive (Bayle 1682: 1, 228-35); in chs. CXX, CXXIII and CXLVI, that idolatry is more obnoxious than irreligion and atheism does not necessarily lead to corruption of morals (Bayle 1682: 1, 315-18; 2, 5-8; 2, 37-9); in chs. CXXXIV - CXXXVIII, that experience shows that religion fails to correct vicious inclinations because, more than on principles they profess, men tend to act on particular judgements dictated by the passion prevailing at the moment (Bayle 1682: 2, 8-18).

The second work is the Dictionnaire historique et critique. From this, just two excerpts are reported. The first, from note B in the entry 'Anabaptistes', reports that excesses by this sect offered the Roman party an occasion to defame Reformation, and that the Reformers, in order to confront competition 'shouted with all their strength' against the Anabaptists (Bayle 1697, 1: 200). The other is from note 1 to the entry 'Gregoire I' and it reports the anecdote of a monk at Pavia Chartreuse pointing to Giangaleazzo Visconti's burial place as that of a 'great saint', and justifying such qualification by the maxim followed in his own country, namely, to "call saints all those 
who do us good'; Bayle comments that this maxim, far from being a typical Italian product, 'is followed at every time and in every country' (Bayle 1697, 2: 598).

Ricardo carefully read more entries. In letters to Mill of 12 Sept. 1817 (Ricardo 1951-1973, 7: 190) and 9 Nov 1817 (Ricardo 1951-1973, 7: 206) he mentions those on 'Manichéens' (Bayle 1697, 3: 302-7), 'Pauliciens' (3: 624-636), and 'Marcionites' (3: 314-9). These discuss the doctrines of the sect of Manicheans or Paulicians - as they were named in Armenia - and of that of Marcionites. These sects used to set the merciful God of the New Testament against the allegedly merciless God of the Old Testament. The point Bayle wants to make here is that it is hard to account for the existence of evil without allowing for two original co-existing principles, and that to refute this idea is even more difficult for Christians than for the polytheists, since they are bound either to deny God's omnipotence or to make God the author of evil.

The second notebook, probably from 1818, includes an excerpt from ch. 14 of John Locke's Reasonableness of Christianity which declares that among the ancient Heathens some philosophers cultivated the knowledge of one God, but few went to their schools 'to be instructed in their duties', and most people rested content with sacrifices and services, while 'the priests made it not their business to teach them virtue' (Locke 1695: 147).

Besides, there are two excerpts from David Hume's Natural History of Religion. The first is from sect. 12, declaring that in all ages religious conviction 'is more affected than real', and 'the assent in these matters is some unaccountable operation of the mind between disbelief and conviction, but approaching much nearer the former than the latter' (Hume 1757: 72); the other, from sect. 14, declares that the virtuous man 'is drawn to his duty without any effort or endeavour' by the force of the natural ties he has with his family and community, to which a 'sentiment of order and moral beauty' is joined, without any 'pretence to religious merit; and the virtuous conduct is deemed no more than what we owe to society and to ourselves' (Hume 1757: 82).

Reading notes follow from two works by Richard Watson, the Regius Professor of 
Divinity at Cambridge and Bishop of Llandaff, An Apology for Christianity (1776), being a rejoinder to Edward Gibbon, and An Apology for the Bible (1796), being a rejoinder to Thomas Paine. The first excerpt from the former book says that it is just as illiberal in Divines, to attribute the scepticism of every Deist to wilful infidelity; as it is in the Deists, to refer to the faith of every Divine to professional bias' (Watson 1776: 86-7). The next declares that Gibbon's polemics against miracles go beyond the point by relying on an idea of unchangeable laws of nature as if they were fully known (Watson 1776: 92-6), while there 'was a time no one was acquainted with the laws of magnetism; these suspend in many instances the laws of gravity; nor can I see, upon the principle in question, how the rest of mankind could have credited the testimony of their first discoverer; and yet to have rejected it, would have been to reject the truth' (Watson 1776: 92).

Three excerpts follow from An Apology for the Bible, the first on fairness in controversy: 'A philosopher in search of truth forfeits with me all claim to candour and impartiality, when he introduces railing for reasoning, vulgar and illiberal sarcasm in the room for argument' (Watson 1796: 29). The second is a defence of prophecies from the Hebrew Bible (Watson 1796: 160-2). The third is about Deism, arguing that it runs into the same difficulties as revealed religion (Watson 1796: 367-9), among these 'the existence of evil, moral and natural, in the work of an infinite being, powerful, wise, and good' and 'the gift of freedom of will, when the abuse of freedom becomes the cause of general misery' (Watson 1796: 369).

The last notes are from An Examination of the Bishop of London's Discourse concerning Prophecy by Conyers Middleton, a Cambridge fellow with a taste for theological controversy. The first excerpt is again on fairness in controversy. It declares that the Bishop 'forgot surely that he was now discoursing from the Press, and not from the Pulpit: for though Ipse dixits may carry authority with them, where no body can contradict, yet they would never pass for arguments, where speech and debate are free' (Middleton 1750: 35). The second is about 'questions, wholly speculative, fruitless and inexplicable', arguing that 'the foundation of all religion' lies in 'those practical, social 
and real duties, which our reason and senses prescribe in common to all' (Middleton 1750: 196-7).

To draw a balance, it would be a risky enterprise to try to evince Ricardo's own opinions from evidence of what he found noteworthy. Nonetheless, fixing a list of topics he deemed worth discussing would already be a result of some interest. A reasonable list might be as follows: (i) the existence of the tendency to believe whatsoever opinion on authority; (ii) the need for mutual respect in religious controversy; (iii) the ethical character of all true religious teaching; (iv) the superstitious and immoral character of religion reduced to ceremonies and sacrifices; (v) the possibility of morality without a foundation on religious belief and falsity of allegations of immorality against Atheism; (vi) the irrelevance of speculative theology; (vii) the irrelevance of Deism as an alternative to revealed religion as being just one more speculative theology leaving decisive questions unanswered; (viii) the miscarriage of all philosophical trials in theodicy. This is no more than an agenda for discussion, and yet there is enough to refute a number of claims advanced by some commentators.

\section{Theodicy in the correspondence with Mill}

The last point listed above, namely the impossibility of any theodicy, was again discussed by Ricardo on other occasions, when he manifested his interest in the issue and expressed the opinion that all philosophical trials in theodicy had miscarried - note that among these were those staged by the young Malthus, Paley, Sumner, and the mature Malthus - thus taking a stance close to Kant's refusal of theodicy, of which he was obviously enough unaware. But he also rejected - as politely as ever - Mill's implication that the failure of any theodicy leaves Atheism as the only option. In fact, while discussing Bayle in letters to Mill of 12 Sept 1817 (Ricardo 1951-1973, 7: 190) and 9 Nov 1817 (Ricardo 1951-1973, 7: 206) he writes:

On these difficult points I keep my mind in a state of doubt from which in this world I never can be relieved. To account for evil in a world governed 
by a Being of unbounded benevolence and power is or appears to be impossible. It is as puzzling a question now as in the early times of which Bayle writes. Is it much different from the Manichean heresy to say that the Creator's benevolence is unbounded, but that his power is limited - and thus to account for evil? (Ricardo 1951-1973, 7: 206; my emphasis) ${ }^{5}$.

Mill answers, on 3 December 1817, that he completely agrees with the last remark, for supposing that God's power is limited amounts to supposing 'that there is some power in the universe, which the Deity cannot controul, and which has a tendency to produce evil' (Ricardo 1951-1973, 7: 212). But, while Ricardo's implication was that all philosophical trials in theodicy will end up with miscarriage, and we can hope at most for an answer to the question on the causes of evil in a world to come, Mill typically presumes that this is a water-proof reason for Atheism, and goes on attacking alleged hypocrisy by somebody else. In fact, he adds: 'Poor Mr. Malthus - If I am not mistaken, it is he who solves the difficulty about the existence of evil in this manner. What a misfortune - what a cruel misfortune, it is, for a man to be obliged to believe a certain set of opinions, whether they be fit, or not, to be believed! (Ricardo 1951-1973, 7: 212-3). That is, he presumes that Malthus, while being obviously aware of the undeniable conclusion he has presented, goes on - unlike virtuous Mill who consistently abandoned the career of 'a priest' for which he had been educated - teaching what he cannot obviously believe in order to keep his own 'prebends'. Besides the usual arrogance it betrays, the comment is particularly inept in failing to notice changes in Malthus's theodicy, from 1798 to 1803 and 1817 (Cremaschi 2014: 79-81, 94-99, 14551) and assuming that - plausible or implausible as it might be - it was still the 1798 one which invited precisely such criticism.

Note that Ricardo's answer of 18 Dec 1817 politely avoids comments on Mill's own presumptions and instead introduces what is perhaps an indirect objection. He

5 King (2013: 32) writes that, even though we cannot establish Ricardo's views on religion, at least this letter proves that he was 'agnostic on the problem of evil'. The comment is misleading, for agnosticism is the claim that we cannot answer the question of God's existence while theism without theodicy is a respectable enough tradition. 
shifts to a comment about religion within a discussion of Mill's recently published History of British India (Mill 1817) that he had started to read. He writes that Mill's own view of the manner in which 'mankind become acquainted with the idea of the Supreme Being is much the same as that of Hume' (Ricardo 1951-1973, 7: 229) and 'the adulatory expressions' with which primitives address him are no proof 'of any just or sublime conception of him' (Ricardo 1951-1973, 7: 229). This is perhaps a polite but malicious way of responding, for Mill did not admit of 'any just or sublime conception' of God but just rejected any conception of God.

Besides the opinions that both metaphysics and speculative theology are vain enterprises, the idea that theodicy is a risky business is something else that Ricardo had heard at Unitarian 'instructions'. Like every other eighteenth-century philosopher, Priestley had tried to solve the problem of evil, and his solution resembles Leibniz's solution. He writes that, since 'all evils and inconveniences have final causes', once the final cause has ceased to exists, 'evils tend to be eliminated by themselves' (Priestley 1762: 250), and even

everything painful and disagreeable in the world appears to a philosopher [...] to be excellently provided as a remedy of some greater inconvenience, or a necessary means of a much greater happiness; so that, from this elevated point of view, he sees all temporary evils and inconveniencies to vanish, in the glorious prospect of the greater good to which they are subservient (Priestley 1767: xvii).

Belsham writes, in a first phase, that philosophical necessitarianism is an appealing doctrine also in so far as 'it demonstrates the inseparable connexion between moral and natural evil, and proves that by the established course of nature every vice shall be followed by adequate punishment' (Belsham 1801: 310), that 'the preponderance of happiness' is 'very considerably on the side of virtue' and, 'generally speaking, every purpose of substantial justice is answered independent of a future state' (Belsham 1801: 351); this doctrine is also 'inseparably connected with that of optimism', showing that all events are 'necessary parts of a great system, which shall eventually produce the greatest possible sum of happiness and virtue, both to the universe and to individuals' 
(Belsham 1801: 313). Yet, later on, he writes that, when we consider the world as a whole, 'we see enough' to be satisfied

that the result of it is a great preponderance of good [...] but when we consider the divine dispensations in detail, we shall immediately discover that they are far beyond the reach of human sagacity (Belsham 1826 - 1827, 2: $36-7)$

and the fact 'that evil, natural and moral, is unavoidable in the works of God, is a problem of very difficult solution' (Belsham 1826 - 1827, 2: 37). To sum up: the only admissible argument to reconcile the Creator's goodness and what experience proves about the course of the world is that the amount of good may overwhelm the amount of evil in the long run, but we can neither prove this in a totally convincing way nor can we explain evil-in-the-short-run away as being merely apparent.

\section{Theodicy in the correspondence with Malthus}

In the Essay on Profits of 1815 Ricardo mentions Providence. He apparently wants to draw from one of Malthus's claims such further implications as to lead to implications opposite to the original ones. He notes that

it has been remarked, in reference to a single country, that if the crops are bad in one district, they are generally productive in another; that if the weather is injurious to one soil, or to one situation, it is beneficial to a different soil and different situation; and, by this compensating power, Providence has bountifully secured us from the frequent recurrence of dearths. If this remark be just, as applied to one country, how much more strongly may it be applied to all the countries together which compose our world? Will not the deficiency of one country be made up by the plenty of another? (Ricardo 1951-1973, 4: 31).

To be fair, God is mentioned here in the context of a tu quoque argument, and thus his mention cannot be assumed to imply direct commitment to his existence.

A similar, but somewhat more committed, concession is made in his Notes on Malthus. His objection concerns the latter's qualification of rent as a 'bountiful gift of 
Providence' and the argument is that rent comes from limited resources such as land, but not from unlimited ones, and that it is scarcity, not intrinsic usefulness, to give a price to scarce resources. Thus the problem for a political economist is not

whether the Creator did not consult our real happiness by limiting the productive powers of the land, but whether the fact be not, that he has so limited it, - while He has given us an unbounded supply of water, of air, and has set no limits to the use we may make of the pressure of the atmosphere, the elasticity of steam and many other services rendered to us by nature (Ricardo 1951-1973, 2: 210; cf. 337-8).

On balance, Ricardo's argument seems to be in favour of a less value-laden approach in economic theory. Note that he does mention the Creator here and in the previous quote he had not hesitated in mentioning Providence. It is true that both mentions are made for the sake of the argument, namely, that he is drawing implications from Malthus's own argument while trying to refute it by a reductio ad absurdum. Yet, he seems to mention the Creator or Providence without any special caution. It seems that the argument here is both of a tu quoque nature and one that Ricardo could seriously endorse, even though with opposite conclusions. His main concern seems to be exclusion not of religion but of 'metaphysics'; that is, he wants to rule out our capacity to detect an axiological and teleological order in the world and to fix boundaries to the scope of human knowledge. In more detail, he wants to confine human knowledge to the discovery of correlations and formulation of general laws. This may depend in turn on limited scepticism, one of the doctrines taught by Belsham. In a word: he seems to favour a more 'secular' approach to political economy but, in more detail, he favours a more secular approach in so far as he favours a more 'modest' view of the science or a more limited view of its scope, amounting to the study of correlations between observable magnitudes. Thus he seems to believe that political economy has in Malthus's own words turned upside down - less 'resemblance to the sciences of morals and politics' than to 'the science of mathematics' (Malthus 1820, 2: 518; cf. Cremaschi 2010). This view in turn is inspired, rather than by a Cartesian or rationalist trust in the unlimited powers of human knowledge, by moderately sceptical awareness of its limits (Cremaschi and Dascal 1996: 495-504; 1998: 248-9). In turn, this did not 
result from the attitude of a 'true scientist' in contrast with the allegedly muddled, moralizing attitude of priest Malthus; on the contrary, we face here one of the many billiard-ball effects with which the history of science at large is disseminated, namely, secularizing consequences of a theological doctrine (Cremaschi 2002).

\section{The impossibility of theodicy and its consequences for political economy}

Ricardo's views on the possibility of faith and the impossibility of theology, the independence of morality from religion and unbounded freedom of enquiry are of remarkable interest for a reconstruction of both his biography, political views and activity as a politician and philanthropist and the intellectual background - natural science, philosophy, theology, political theory - against which his contributions to political economy took their course. This would be enough to make the present reconstruction of some interest to historians of economic thought too. But what is especially important for them is the most typically theological theme - and apparently most abstruse one - theodicy.

In 1798 Malthus had characteristically tried to square the circle of asymmetry between growth of resources and growth of population by means of a very particular kind of theodicy introduced in order to fill the gap. He had been attacked on every side, one of them being Christian charity, and had carried out an egregious retreat in several steps, while claiming he had always been right. In Ricardo's Library there was a copy of Malthus's Essay on Population, $5^{\text {th }}$ ed. 1817 (Sraffa 1955b: 398). This suggests that he read this work in the 1817 edition and, by implication, that he may have been exposed to Malthus's own theodicy in its third version, which was different from the original as well as from the already revised 1803 one. Besides, as documented in the 'Commonplace Book', it was precisely in 1817 that Ricardo started reading Bayle's work. The fact that the discussion of theodicy in the correspondence with Mill also 
dates from the last months of that year suggests that Ricardo's interest in theodicy did not arise from a sudden conversion from economic to religious interests, but was precisely occasioned by the tangle that political economists of the time were trying to untie, namely the growth of wealth and its link with poverty, that is, the causes of social evil or the viability of some kind of social theodicy. Let me add that Malthus's discovery of the principle of population occurred in the context of a refutation of a new kind of theodicy, that is, the atheistic anthropodicy centred on an idea of unlimited human perfectibility proposed by William Godwin and the Marquis of Condorcet (Cremaschi 2014: 79-84). This was just one step in an on-going process transforming theodicy from a highly abstract discussion into 'applied theology', hardly any strange invention by Malthus himself. In fact, the eighteenth-century discussion of population was mainly of a theological kind, exploring the role of divine providence behind the growth and decrease of population, shifting from discussion of the causes of metaphysical, physical, and moral evil - or of human finitude, suffering, and wickedness - to that of the causes of misery and vice unavoidably going with misery (La Vergata 1990: 20-40).

Let me recall briefly what Malthus' theodicy was originally and how it was restyled in its third 1817 version. The eighteenth-century Anglican ethics to which Malthus was exposed while at Cambridge elaborated on Richard Cumberland's attempt to mark a third way between the intellectualist and the voluntarist view of the law of nature, yielding a rational-choice account of natural law, where a law-giver God chooses from among a number of possible sets of laws on the basis of a maximandum, happiness for his creatures. Such a solution tried to settle at once the problem of evil and the foundation of moral obligation by proving that God's choice is justified in so far as it is the one that reduces the mass of suffering in the world to a minimum. Malthus's 1798 theodicy tried to prove that evils deriving from action of the principle of population were partial evils in so far as they enforced exertion by human beings, thus transforming matter into mind (Malthus 1798: 97-101; cf. Cremaschi 2014: 764-7). A second version, based on William Paley's Natural Theology, is presented in the 1803 Essay. It contends that there is a moral order in the world, less tragic than the one of the 
first Essay, and it depends on the possibility of avoiding evils carried by the principle of population through a combination of prudence and chastity. Once it has been proved that the passions may be dominated, and that a world where passions are under control would be a comparatively happy place, the world turns out to be not an evil place, and its Creator to be omniscient, benevolent, and perhaps also omnipotent (Malthus 1803, 2: 88-95; cf. Cremaschi 2014: 94-9). A third version is presented in the $18175^{\text {th }}$ edition, arising from reaction to criticism by evangelical authors such as John Sumner and Thomas Chalmers. In this version moral improvement becomes the variable to be maximised in the divine plan. The resulting new theodicy is more prudent than both former versions, amounting either to the Cambridge Platonists' optimism made softer or to a claim analogous to the Kantian one of the failure of any theodicy. The signs of this change are, first, that inequality and poverty are no longer accepted in a Paleyite fatalist spirit and that existing conditions of society are now justified on the argument, not that they are the happiest available, but that they are the most favourable to moral development; secondly, that population growth is now not an actual cause of social evil but just an always present potential cause, and that its negative effects can be effectively checked by moral constraint, that is, delayed marriage without irregular gratification, in turn made possible by, or going together with, more education, more self-respect, and more self-reliance (Malthus 1803, 1: 19; 2: 214-5, 251; cf. Cremaschi 2014: 145-55).

James Mill was far from immune from such concerns. If we are to believe his son's account, among the reasons for his decision to abandon the profession of Presbyterian preacher for which he had been educated, there was 'a state of perplexity' when facing 'a world so full of evil' that made it impossible to believe that such a world 'was the work of an Author combining infinite power with perfect goodness and righteousness' (Mill 1873: ch. 2). And, oddly enough, in his own Elements of Political Economy, apparently an axiomatic and deductive introduction to the economic science, he smuggles in an attempt to settle the problem of social theodicy. First he argues, in a factual tone, that, if the condition of 'the great body of the people' is not easy and comfortable, it can only be made so by one of two methods: either by quickening the rate at which capital increases, or retarding the rate at which population increases (Mill 
1821: 44), and, if we cannot secure 'human happiness' by making capital increase as fast as population, the practical problem is to find a way to limit the number of births (Mill 1821: 65). He then goes on to argue that a sociological, not purely economic, fact should also be taken into account. The possibility that mankind may advance in knowledge and discover ways to take more command over the means of happiness depends 'upon the existence of a class of men who have their time at their command; that is, who are rich enough to be freed from all solicitude with respect to the means of living in a certain state of enjoyment. It is by this class of men that knowledge is cultivated and enlarged' (Mill 1821: 63). This would not be so bad, if Mill did not shift without previous notice, from cause-effect relationships to value judgments. In fact he adds:

What is the class of men by whom the greatest happiness is enjoyed, [...] they who are raised above solicitude for the means of subsistence and respectability $[\ldots]$ the men of middle fortune $[\ldots]$ who, having their time at their own disposal, freed from the necessity of manual labour, subject to no man's authority, obtain, as a class, the greatest sum of human enjoyment. For the happiness, therefore, as well as the ornament of our nature, it is peculiarly desirable that a class of this description should form as large a proportion of each community as possible (Mill 1821: 64; my emphasis).

Note that this is no longer value-free scientific consideration, being rather a moral evaluation of the condition of society. And here, after having applied the Malthusian principle of population in its original crude version, he also applies without spelling it out - the Benthamite principle of utility also in its crude original formulation, where only the total amount of happiness is taken as a criterion of justice, with the twofold effect of transforming a purely theoretical discussion of economic laws into a normative theory of justice, and of introducing a Calvinist atheist doctrine of predestination according to which only a few - here, the middle class - are destined for salvation and everyone else should be happy and content for them.

Robert Owen too was no stranger to these problems. It is worth reporting a table-talk remark by Ricardo on Owen's views, reported in John Lewis Mallet's diary (14 Jan 
1820) on free will, necessitarianism, theodicy and, remarkably, the possibility to fight social evils. He writes:

Ricardo knows Owen intimately. He says that he is a thorough necessitarian; but being at the same time a Deist, he believes that all works for the best. It were to be wished, upon this principle, that he would be less pertinacious in his efforts to alter the state of society (Ricardo 1951-1973, 8: 153).

If we try to spell out the full implications of this comment, we might - with due caution - head towards the conclusion that Ricardo was implying the following: (i) belief that all works for the best or, in eighteenth-century philosophical jargon, Optimism, or the claim that there is an answer to the question on evil, carries a paradox, the same as the one Adam Smith pointed out with regard to Stoicism, that is, it makes moral judgment and action unnecessary; (ii) the above optimistic belief derives from a combination of necessitarianism and Deism. This comment, no less than Ricardo's comments in the correspondence with Mill and Malthus, and his reading notes in the Commonplace Book highlight the relevance theodicy had - in Ricardo's view - for the issues of population, the relationship of rent, profits and wages, poverty, the condition of the working class - namely the topics of his chapter on machinery of 1819 that will, by no means coincidentally, occasion Mill's complaint. The fact that our world is not a Panglossian one leaves nonetheless a hope that something better is possible.

His comment on Owen is telling. It points precisely to the link between theodicy and the social question and may shed additional light on the Malthus-Ricardo controversy in so far as it concerns precisely a decisive point in the controversy, namely, the status of political economy, either a science similar to mathematics or a part of 'the science of moral and political philosophy' (Malthus 1820, 1203; cf. Cremaschi 2010). Ricardo's limited scepticism, implying limits to moral knowledge, necessitarianism, the refusal of theodicy, played in favour of the former alternative.

Note that rejection of theodicy in general implied also rejection of Malthus's 1817 version, namely a moral theodicy where evil is justified not as means to more happiness but as a spring for moral improvement. That is, Ricardo's mature view may have been 
that such social evils as poverty ought to be reduced but - unlike Malthus's mature view - they are not made any more comprehensible by such considerations as that they are the spring of moral improvement, and indeed such considerations may border on blasphemy. Thus, waging war on poverty is still a moral imperative, but one that is still in force despite awareness of the tragic character of the human condition.

Ricardo apparently disagrees, for different reasons, with Mill, Owen and Malthus, although it is with Malthus that he has more in common. The claims he seems to reject are:

(a) all work for the best (in Voltaire's phrase, tout est bien);

(b) evil is out there as a means to our moral improvement;

while the claims he seems, instead, to endorse are:

(a) evil is a hard fact for which no account is available;

(b) yet we have a duty to do good, that is, to promote our neighbour's happiness.

Allow me to make a step forward and then come back. Max Weber, in his sociology of religion points at one basic function of religions, namely providing an answer to the question of the origins of evil. In his famous 'Zwischenbetrachtungen' he argued that, in a 'rationalized' world, the tension becomes obvious between a rationalized economy and a religion that has itself been rationalized. Thus, 'the religions of salvation have had a tendency to depersonalize and objectify love in the unique sense of acosmism. Yet [they] have watched with profound suspicion the deployment of economic forces which [...] have likewise become impersonal' (Weber 1915: 331). In such religions, typically, the precept of love becomes universalized and every human being becomes a brother or sister, but this is bound to clash with the logic of the market where every human being, in an analogous universal way, tends to become one more magnitude in the quantified world of the market. He adds that money 'is the most abstract and "impersonal" element that ever existed. The more the world of 
the modern capitalist economy follows its own immanent laws, the less accessible it is to any imaginable relationship with a religious ethics of brotherliness' (Weber 1915: 331). Ricardo somehow probably sensed Weber's tension and went looking for a way out of it, while keeping his conviction of the existence of severe limits to human knowledge in mind, and thus refused to accept any of the social theodicies or anthropodicies that had been formulated - Godwin's, the young Malthus's, Mill's - as intellectually arrogant and blasphemous. His final view was perhaps not too far, in terms of policies, from Malthus's last views but - we may speculate - still with one point of disagreement in terms of speculative issues. The point may have been that even a moral theodicy - that is Malthus's 1817 version - according to which social evil is there to provide an occasion for moral improvement would have been for him both intellectually unwarranted and morally repugnant. To the question why there are poverty, destitution, diseases, high rates of mortality the only intellectually and morally acceptable answer is: we don't know.

This attitude, resulting from awareness of the existence of serious limits to human knowledge - both theoretical and moral - and the preoccupation of usefulness of knowledge is what marks Ricardo's modest research program in political economy, a program whose spirit has been most of the time misunderstood by commentators as a kind of arrogant aprioristic deductivism mistaking idealized assumptions for the real world. It was precisely this attitude that was mistaken, shortly after his death, by his admirer Marx for a 'Stoic, objective, scientific' attitude (Marx 1965 - 1968, 2: 112) and by his detractor Leslie Stephen for lack of 'human feeling' (Stephen 1900, 2: 222)

\section{Conclusions}

\footnotetext{
${ }^{6}$ To tell the whole truth - one disgusting enough to deserve being confined to a footnote - he wrote that Ricardo 'was a Jew' and 'Jews, in spite of Shylock's assertions [...] are naturally without human feeling' (Stephen 1900, 2: 222).
} 
1. Ricardo was apparently neither an atheist nor an agnostic; but belief and disbelief are existential attitudes, not theoretical claims, whether Ricardo believed or rather doubted - after all, who doesn't doubt? - is not an appropriate question for historians; thus the pertinent question is whether he admitted the possibility of religious belief or instead ruled it out as irrational, and the answer is that his own philosophy was a kind of limited scepticism leaving room for religious belief for whoever would like to avail himself of this option.

2. He argued for toleration not on the basis of the crude argument that religion is a fake - and even less on the even cruder one that, since he was himself an atheist, toleration for atheists was to be defended - but on the more rational one that nobody is the owner of the truth, there are several sets of beliefs that reasonable persons may adopt, and that even those who adopt absurd beliefs cannot be forced to change their beliefs at will.

3. He believed that speculative theology is impracticable and irrelevant in so far as it is an attempt to formulate what is unknowable in terms of a scientific truth; note that he was not declaring the impossibility of faith, he was just declaring that formulating theological doctrines is an impracticable task; he was not advancing an argument in favour of atheism but one more argument against dogmatism and intolerance.

4. He believed that morality is independent of revelation, that there is a natural morality accessible to every reasonable mind independent of different religious beliefs; note that this is typical Enlightenment staple shared by deist, theist, and liberal Christian thinkers; besides, that it is not a peculiarly 'modern' view, being just an old antiAugustinian and anti-Calvinist doctrine defended in the Middle Ages by Aquinas and William of Ockham, and in modern Britain by every enemy of religious fanaticism, from the Cambridge Platonists to Richard Price, Francis Hutcheson and Adam Smith.

5. He concluded that theodicy is impossible for the same reasons Kant advanced in order to prove 'the miscarriage of all philosophical trials in theodicy' and, unlike James Mill, believed that such conclusion is no argument for unbelief but rather one 
more argument for moral responsibility vis-à-vis poverty, against the kind of dogmatic laissez-faire optimism Mill and others were prone to adopt.

6. Besides believing that, even though what every religion has to teach is precisely morality, the latter comes before religion and it is 'autonomous' in a somewhat Kantian sense; that is, he rejected the prevailing Anglican doctrine shared by Malthus that the moral law is a path to happiness and that virtue will be rewarded; for him a sense of duty - including a duty to fight poverty - derives from reason, may be further confirmed by faith, but could hardly be grounded in the certainty that virtue will be rewarded.

7. And he believed that social science should be a secular science precisely for theological reasons; in other words, leaving the biographical question aside, the antidogmatic kind of religious belief to which Ricardo possibly adhered, but that certainly declared to be fully legitimate, ruled out both Malthus's moral and political science and Mill's Laissez-Faire Metaphysics.

\section{References}

\section{Unpublished material}

Ricardo Papers. Miscellaneous Private. Cambridge: Cambridge University Library.

\section{Published material}

Aspland, R. et al. (1823). The Christians' Petition to Parliament against the prosecution of unbelievers. The Monthly Repository, 18 (210), pp. 362- 4. 
Bayle, P. (1682) [1939]. Pensées diverses sur la comète, 2 vols, ed. A. Prat. Paris: Droz

Bayle, P. (1740) [1697]. Dictionnaire historique et critique. 4 vols. Amsterdam: Brunel.

Belsham, Th. (1826 - 1827). Discourses, Doctrinal and Practical; delivered in Essex Street Chapel, 2 vols. London: Hunter.

Bowring, J. (1877). Autobiographical Recollections of Sir John Bowring. London: King.

Cremaschi, S (2010). Malthus's idea of a moral and political science, The Journal of Philosophical Economics, $3 \backslash 2$ (2010), pp. 5-57.

Cremaschi, S. (1994). Review of M. Milgate and Sh.C. Stimson 'Ricardian Politics'. The European Journal of the History of Economic Thought, 1, pp. 622-4.

Cremaschi, S. (2002). Two views of natural law and the shaping of political economy. Croatian Journal of Philosophy 2 (5), pp. 181-96.

Cremaschi, S. (2004). Ricardo and the Utilitarians. The European Journal of the History of Economic Thought, 11, pp. 377- 404.

Cremaschi, S. (2014). Utilitarianism and Malthus's Virtue Ethics. Respectable, virtuous and happy. Abingdon, UK: Routledge.

Cremaschi, S. (2015). Belsham Thomas and Ricardo. In H. Kurz, N. Salvadori (eds), The Elgar Companion to Ricardo, Aldershot: Edward Elgar.

Cremaschi, S. (forthcoming). Invisible Beings. Adam Smith's lectures on natural religion. The Adam Smith Review, 10.

Cremaschi, S. and Dascal, M. (1996). Malthus and Ricardo on economic methodology. History of Political Economy, 28, pp. 475-511. 
Cremaschi, S. and Dascal, M. (1998). Malthus and Ricardo: two styles for economic theory. Science in Context, 11, pp. 229-254.

Cremaschi, S. and Dascal, M. (2002). The Unitarian connection and Ricardo's scientific style. History of Political Economy, 34, pp. 505- 8.

Dave, D. (1978). A Gathered Church. The Literature of the English Dissenting Interest, 1700-1930. Abingdon: Routledge.

Depoortère, Ch. (2002). On Ricardo's method: The Unitarian influence examined. History of Political Economy, 34, pp. 499-504.

Hartwell, R.M. (1971). Introduction. In D. Ricardo, The Principles of Political Economy and Taxation. Harmondsworth: Penguin.

Henderson, J.P. (1997). The Life and Economics of David Ricardo. With additional chapters by J.B. Davis. Dordrecht: Kluwer.

Hume, D. (1757) [2007]. A Dissertation on the Passions. The Natural History of Religion, ed. T. L. Beauchamp. Oxford: Clarendon.

King, J. E. (2013). David Ricardo. Houndsmill: Palgrave Macmillan.

La Vergata, A. (1990) Nonostante Malthus. Fecondità, popolazioni e armonia della natura. 1700-1900. Torino: Bollati Boringhieri.

Lindsay, J. (1813). A Sermon on the Influence of Religious Knowledge as Tending to Produce a Gradual Improvement in the Social State. London: Johnson.

Locke, J. (1695) [1999]. The Reasonableness of Christianity, ed. J.C. HigginsBiddle. Oxford: Clarendon.

Malthus, T.R. (1820 [1989]). Principles of Political Economy, ed. J. Pullen. Cambridge: Cambridge University Press.

Malthus, Th. R. (1798 [1986]) An Essay on the Principle of Population. In: The 
Works of Thomas Robert Malthus. Vol. 1, ed. Wrigley, E. A. and Souden, D. London: Pickering.

Malthus, Th. R. (1803 [1989]) An Essay on the Principle of Population. The Version Published in 1803, with the Variora of 1806, 1807, 1817 and 1826, ed. James, P. Cambridge: Cambridge University Press.

Malthus, Th. R. (1989) [1820]. Principles of Political Economy. Variorum edition, ed. J. Pullen. 2 vols. Cambridge: Cambridge University Press.

Marx, K. (1965 - 1968). Theorien über den Mehrwert. 3 vols. Berlin: Dietz (Marx \& Engels Werke, 26/1-3).

Middleton, C. (1750). An Examination of the Bishop of London's Discourse concerning Prophecy. London: Manby and Cox.

Milgate, M. and Stimson, Sh.C. (1991). Ricardian Politics. Princeton: Princeton University Press.

Mill ([1821] 1844). Elements of Political Economy. Third edition. London: Routledge / Thoemmes Press

Mill J.S. ([1873] 1981). Autobiography. In Autobiography and Literary Essays, ed. J.M. Robson and J. Stillinger. Toronto: University of Toronto Press

Mill, J. (1817) [1997]. History of British India, 10 vols, ed. H.H. Wilson. London: Routledge.

Paley, W. (1802) [1970]. Natural Theology. Westmead: Gregg.

Priestley, J. (1762) [1972]. A Course of Lectures in the Theory of Language and Universal Grammar. In The Theological and Miscellaneous Works, ed. J.T. Rutt. New Yok: Kraus Reprint, vol. 23.

Priestley, J. (1767) [1775]. The History and Present State of Electricity with Original Experiments. London: Bathurst. 
Ricardo, D. (1951 - 1973). The Works and Correspondence. 11 vols. Cambridge: Cambridge University Press.

Sraffa, P. (1955a). Addenda to the Memoir. In D. Ricardo, The Works and Correspondence. 11 vols. Cambridge: Cambridge University Press, vol. 10.

Sraffa, P. (1955b). Appendices. In D. Ricardo, The Works and Correspondence. 11 vols. Cambridge: Cambridge University Press, vol. 10.

Stephen, L. (1900). The English Utilitarians. 3 vols. London: Duckworth.

Stuart, A. (2003). Unitarian radicalism. Political Rhetoric, 1770-1814. London: Palgrave Macmillan.

Sumner, J.B. (1816). A Treatise on the Records of the Creation and on the Moral Attributes of the Creator. London: Hatchard.

Trower, H. (1813). Christianity in India. - Letters bewteen Laicus and An East India Proprietor as they appeared in the Times Newspaper in the Months of August, September and October, 1813. London: Rivington.

Watson, R. (1776). An Apology for Christianity. Cambridge: Merrill.

Watson. R. (1799) [1796]. An Apology for the Bible. London: Evans.

Watts, R. (1998). Gender, Power and the Unitarians in England 1760-1860. London: Longmans.

Weatherall, D. (1976). David Ricardo. A Biography. The Hague: Nijhoff.

Weber, M. (1915 [1975). Religious rejections of the world and their directions. In M. Gerth and C. Wright Mills eds. From Max Weber: Essays in Sociology. New York: Oxford University Press, pp. 323-59.

Williams, J. (1833). Memoirs of the Late Reverend Thomas Belsham. London: printed for the author. 


\begin{abstract}
I review evidence from published and unpublished sources on Ricardo's theological ideas. The main focuses of interest are the existence of a natural morality independent of religious confessions, morality as the essence of religion, useless of theological speculation, justification of toleration for everybody, including atheists, and the miscarriage of any attempt at a philosophical theodicy. The paper explores also the connection between Ricardo's interest for theodicy and his views on the scope and method of political economy and suggests that his opinion that political economy should be a secular and value-free science close to mathematics depends precisely on theological reasons.
\end{abstract}

\title{
Keywords
}

David Ricardo; political economy; toleration; theology; theodicy 